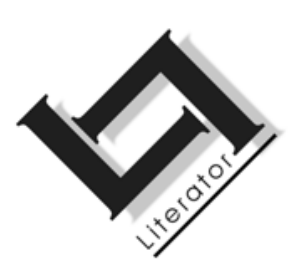

\title{
Teks op teks op teks: intertekstualiteit in Ingrid Winterbach se Niggie
}

\author{
Marisa Botha \& Helize van Vuuren \\ Departement van Taal en Letterkunde \\ Nelson Mandela Metropolitaanse Universiteit \\ PORT ELIZABETH \\ E-pos: marisa@webafrica.org.za \\ helize.vanvuuren@nmmu.ac.za
}

\begin{abstract}
Text on text on text: intertextuality in Ingrid Winterbach's Niggie
\end{abstract}

This article focuses on the creative adaptation of Anglo-Boer War material in Ingrid Winterbach's (formerly Lettie Viljoen) "Niggie" ("Cousin") (2002) with specific reference to the historiographical-metafictional element and intertextual game with texts written during or shortly after the Anglo-Boer War in Dutch, such as Totius' "Vier-en-sestig dae te velde: 'n oorlogsdagboek" ("Sixty four days afield: a war diary") (1977) and in English, "Woman's endurance" (1904) by A.D.L. and Deneys Reitz's "Commando: a Boer journal of the Boer War" (1932). The intertextuality of more recent texts such as "Op soek na generaal Mannetjies Mentz" ("In Search of General Mannetjies Mentz") (1998) by Christoffel Coetzee, Klaas Steytler's "Ons oorlog" ("Our war") (2000) and Etienne Leroux's "Magersfontein, O! Magersfontein" (1976) will also be discussed.

A literary analysis is done of the novel "Niggie", with specific focus on the nature and function of Anglo-Boer War material in Winterbach's text. The question is posed why is there such a sustained focus and creative adaptation of Anglo-Boer War texts in Winterbach's oeuvre, especially in "Belemmering" ("Impediment") (1990); "Karolina Ferreira" (1993); "Buller se plan" ("Buller's plan") (1999) and "Niggie" ("Cousin") (2002)? How does she adapt this material? What is the function of this 
process and in what way does this novel impact on the reader a century after the war?

\section{Opsomming}

\section{Teks op teks op teks: intertekstualiteit in Ingrid Winterbach se Niggie}

Hierdie artikel fokus op die kreatiewe verwerking van AngloBoereoorlogmateriaal in Ingrid Winterbach (vroeëre skrywersnaam: Lettie Viljoen) se "Niggie" (2002) met spesifieke verwysing na die historiografies-metafiksionele inslag en intertekstuele spel met oorlogsdagboeke uit hierdie tydperk, soos Totius se "Vier-en-sestig dae te velde: 'n oorlogsdagboek" (1977) en ook in Nederlands, "Woman's endurance" (1904) deur A.D.L. asook Deneys Reitz se "Commando: a Boer journal of the Boer War" (1932). Die intertekstualiteit met meer resente tekste soos "Op soek na generaal Mannetjies Mentz" (1998) van Christoffel Coetzee; Klaas Steytler se "Ons oorlog" (2000) en Etienne Leroux se "Magersfontein, O! Magersfontein" (1976) sal ook bespreek word.

Die artikel fokus op die aard en funksie van die AngloBoereoorlogmateriaal in Winterbach se roman. Waarom die volgehoue fokus en kreatiewe verwerking van Anglo-Boereoorlogtekste in Winterbach se oeuvre, soos veral ook in "Belemmering" (1990); "Karolina Ferreira" (1993) en "Buller se plan" (1999)? Hoe verwerk sy dié materiaal? Wat is die funksie daarvan en wat is die impak op die Afrikaanse leser 'n eeu na afloop van dié oorlog?

\section{Inleiding}

Op merkwaardige wyse is die Anglo-Boereoorlog na 'n eeu steeds 'n topos in die Afrikaanse letterkunde. Hierdie ouer historiese gebeure staan sentraal in Winterbach se oeuvre, met as markante resente voorbeeld die kort roman, Niggie (2002). In dié roman is spore van teks op teks op voorafgaande teks merkbaar wat ook met die AngloBoereoorlog te make het: ouer sowel as meer resente outobiografiese tekste en romans soos Op soek na generaal Mannetjies Mentz (1998) van Christoffel Coetzee en Klaas Steytler se Ons oorlog (2000).

Herkenning van die intertekste ${ }^{\mathbf{1}}$ van Jan F.E. Celliers, ${ }^{2}$ Totius en talle ander, maak duidelik dat Niggie 'n komplekse en verwikkelde

1 Die term intertekstualiteit word gebruik in die "hedendaagse literatuurstudie om aan te duiden dat een literaire tekst gesitueerd is tussen andere teksten en er 
teks is waarin veral die intertekstuele spel met hierdie AngloBoereoorlogmateriaal 'n opvallende tegniek is. Via die subtiel gesuggereerde vergelyking tussen die (Suid)-Afrikaanse situasie van 'n honderd jaar gelede en vandag kom 'n boeiende gesuggereerde beeld van verandering tot stand, en van dit wat verlore gegaan het in en om die Afrikaanse wêreld. Soos Brink in Duiwelskloof (1998) verlore kennis, kunste en woordeskat herontgin en aanwend, gebruik ook Winterbach in Niggie taalargeologiese ontginning. Haar tegniek is egter anders, met onder meer die

vaak op teruggaat" (Van Gorp, 1998:221). Daar is meer as een benadering tot hierdie tipe studie: "Een intertekstuele benadering (b.v. in de vergelijkende literatuurstudie en in de literatuurgeschiedenis) wordt aldus onderscheiden van een (intra-)tekstuele benadering (d.w.z. beperkt tot de desbetreffende tekst zoals in de literaire kritiek) en een contextuele benadering (d.w.z. vanuit de maatschappelijke context)" (Van Gorp, 1998:221). In hierdie studie word intertekstualiteit hoofsaaklik benader vanuit 'n intertekstuele invalshoek soos gebruik word in die vergelykende literatuurstudie. In die teoretiese besinning oor intertekstualiteit, wat geïnspireer is deur die Russiese filosoof, Mikhail Bakhtin, word die onderhawige teks beskou as ingeskryf in die kader van ander tekste en daaruit verkry hierdie teks 'n eie betekenis: "hij plaatst zich in een genretraditie (generieke intertekstualiteit), of verwijst naar andere teksten b.v. door parodie, allusie, citaat" (Van Gorp, 1998:221-222). Die term intertekstualiteit (Latyn: "inter", "tussen") is in 1969 deur Julia Kristeva (1969:146) gemunt in Sémiòtiké: "tout texte se construit comme mosaïque de citations, tout texte est absorption et transformation d'un autre texte. À la place de la notion d'intersubjectivité s'installe celle d'intertextualité ...". Sy benader die literêre werk as teks vanuit 'n semiotiese hoek en sien literatuur as 'n netwerk van interrelasies waarin die verskillende tekste as tekens fungeer wat na mekaar verwys. Maar die begrip teks is vir haar nie net beperk tot talige tekens nie (Kristeva, 1980:37). "The concept of text as ideologeme determines the very procedure of a semiotics that, by studying the text as intertextuality, considers it as such within (the text of) society and history." Volgens haar is 'n literêre teks "a permutation of texts, an intertextuality: in the space of a given text, several utterances, taken from other texts, intersect and neutralize one another" (Kristeva, 1980:36).

In die semiotiek kry die term intertekstualiteit 'n ruimer toepassing: "Men bedoelt er dan mee dat al wat ons omgeeft als 'tekst' kan worden beschouwd, b.v. de cultuur, de politiek, enz. De talige tekst, i.c. het literaire werk, wordt dan gesitueerd tegenover deze 'teksten'" (Van Gorp, 1998:222). Hierdie teksgebeure word beskou as 'n weefproses (Latyn: textus = weefsel) waarby elke betekenis in ander betekenisse ingeweef word: "De tekst is een betekenisknoop die naar verschillende culturele codes verwijst. Het geheel van codes dat de cultuur uitmaakt, is op een gelijkaardige manier ineengestrengeld tot een textuur" (Van Gorp, 1998:222). 'n Intertekstuele benadering voorkom die evaluatiewe hiërargie van invloedstudies en die simplistiese aannames daarvan; terwyl dit aan meer resente én ouer tekste 'n gelykwaardige plek in die studieveld toeken, met aandag vir die implikasies wat die interaksie vir al die betrokke tekste het.

2 Die intertekstuele spel tussen Winterbach se Niggie en Jan F.E. Celliers se oorlogsdagboek word breedvoerig in 'n ander artikel bespreek. 
gebruik van lang katalogusse van verwante woorde (Winterbach, 2002:29-30, 172), taalspeletjies te perd, lyste homofone, en vrye assosiasie. Die kreatiewe spel met Afrikaans as taal manifesteer ook in die gedekontekstualiseerde, oënskynlik inkoherente monoloog van die getraumatiseerde Abraham. Veral vier velde word in haar taalargeologie bestryk: taboewoorde (soos die raspejoratiewe samestellings met die gewraakte "k"-term vir 'n swart mens), die name van flora, fauna en gesteentes, naamspel met plekname en plaasname, en kreatiewe of eksperimentele taalspel.

In die aanvanklike resepsie verskyn min oor die intertekstuele aard van die roman. Petra Müller en Louise Viljoen bring Niggie in verband met Christoffel Coetzee se Op soek na generaal Mannetjies Mentz (1998) en Gunther Pakendorf (2002) merk op dat "karakters, aktiwiteite en gesprekke plek-plek voor(kom) soos 'n fiksionele weergawe van Fransjohan Pretorius se Kommandolewe".

Winterbach se werk toon sterk ooreenkomste met dié van Karel Schoeman ten opsigte van 'n soeke na sin en samehang in die landskap en in die geskiedenis, die lang reis die onbekende in, die yl intrige en ook die buitestandersfiguur. Sowel Ben as Reitz is sulke tipe buitestandersfigure.

\section{Vroeëre Viljoen/Winterbach-romans met Anglo- Boereoorlogmateriaal}

In Belemmering, Winterbach se eerste en "grootste" roman staan die soeke na 'n eie identiteit voorop, met twee sentrale verhaallyne vervleg deur die teks. Die eerste is die verhaal van 'n groep mans op 'n geheimsinnige (moontlik militêre) sending iewers in die berge. Hulle bestudeer hulle kaarte, bespreek verskillende strategieë en bespied die landskap terwyl hulle op hul leier, Geelgert, wag. Teenoor dié storielyn is daar die verhaal van Hannah, 'n paleontoloog wat uit die Noorde kom en haar aan die Kaap vestig. Deur middel van terugflitse word ' $n$ familiekuier herroep waartydens herinneringe aan die 1914-Rebellie en die Anglo-Boereoorlog ter sprake gekom het. In 'n derde narratiewe lyn tree 'n ongespesifiseerde generaal $C$ in 'n byna surrealistiese vertelling op.

Hannah vra haar oom en tante ure lank uit oor die familie- en volksgeskiedenis, asook individue se geskiedenis. Hoe meer "leemtes ingevul word, hoe minder kan sy die toekoms bou op die goeie wat uit die verlede gehaal is (so 'n onvolkse volksboek!)" (Swanepoel, 1991). Die familiegeskiedenis hoor sy hoofsaaklik by Tante, en die volksgeskiedenis word aan haar oorvertel deur Oom. 
Dit is opvallend dat generiese familiegerigte naamgewing reeds in Belemmering voorkom en later op selfs uitgebreider wyse in Niggie verskyn.

Daar is ' $n$ raakpunt tussen Belemmering (1990) en Niggie (2002), buiten vir die oorloggegewens, en wel in die verwysing na trieksters. In Belemmering tree Geelgert in absentia as leier op vir die groep mans in die berge. Daar word gesê Geelgert het "éintlik die hand van jou aartstrickster, jou wáre poetsbakker, jou argetipiese gedaanteverwisselaar" (Winterbach, 1990:181). In Niggie kom dié idee van 'n trieksterfiguur tot vervulling met die verskeidenheid trieksters in die roman. Die voor die hand liggendste van dié is Oompie, wat direk by hierdie "trieksterdiskoers" betrek word met: "Oompie ken baie trieks" (Winterbach, 2002:42). Dit is ook opvallend dat die woord "aartstrickster" (Winterbach, 1990:181) in die Engelse vorm (trickster) staan, terwyl dit in Niggie verafrikaans word tot triekster.

Viljoen het reeds uitgewys hoe Winterbach in Belemmering (1990) deur heteroglossie die spanning in die Suid-Afrikaanse samelewing weerspieël (Viljoen, 1993:325):

Deur te wys dat alle taal - ook Afrikaans - bestaan uit 'n verskeidenheid diskoerse wat juis inbeur téén die daarstel van 'n amptelike monoloog, word die ruimte van Afrikaans ten beste aan die leser getoon.

In Niggie is die gereflekteerde konflik in die dialogiese aard van die teks egter van ' $n$ ander aard. Rekonstruksie van 'n fiktiewe vroegnegentiende-eeuse, koloniale Afrikaanse samelewing vir konsumpsie deur reële Afrikaanse lesers van die postkoloniale, een-entwintigste eeu, bring onvermydelik 'n vergelyking van die twee tye se konvensies, taalgebruik en bo alles, geïmpliseerde ideologiese instellings binne dieselfde gemeenskap teweeg. Die afleidings wat uit dié gewaagde naasmekaarstelling, binne die raamwerk van die honderdjarige herdenking van die oorlog tussen 1999 en 2002 gemaak kan word, word egter slegs vaagweg gesuggereer deur verwysings na 'n stryd wat voortgaan en dat spesies uitsterf as hulle tyd uitgedien is, volgens die Darwinistiese evolusieleer. Om egter die roman te lees sonder om na te dink oor die haglike stand van Afrikaans in die twintigste eeu, die toenemende emigrasie van Afrikaanssprekendes en hulle toenemende vervreemding van die polis, sou wees as om oor die relatief intrigelose oppervlakte van die teks heen te skeer. 
In die toegankliker Karolina Ferreira (1993; vertaal as The elusive moth in 2005) staan 'n vrouekarakter op soek na eie identiteit sentraal in 'n patriargale gemeenskap. Die wit psige van die inwoners van die plattelandse dorpie, Voorspoed, op die vooraand van postkoloniale politieke transformasie staan in die fokus.

Die verhaal handel oor 'n entomoloog, Karolina Ferreira, wat na die fiktiewe dorpie Voorspoed in die Noordoos-Vrystaat gaan om navorsing oor 'n seldsame motspesie te doen - hulle oorlewingstrategieë in dié droë, ongunstige omstandighede. Op pad na hierdie Vrystaatse dorpie laai sy die bruin man, Willie September op. $\mathrm{Hy}$ is 'n kenner van medisinale plante en gaan na Voorspoed vir navorsing en om by 'n Argentynse deskundige meer te leer oor natuurgenesing. Karolina se verblyf duur agtien weke en strek vanaf die somer tot in die herfs.

Daar is ' $n$ mistieke element in die roman soos byvoorbeeld Jess se betrokkenheid by Boeddhisme, Adelia se betowering deur mistiek, die waarsêer se voorspelling en die heldersiende Willie wat weet wanneer iemand gaan sterf. Die fortuinverteller en ook Willie met sy bonatuurlike vermoëns is ' $n$ raakpunt met die magiese in Niggie.

Die heldersiende Willie is moontlik 'n uitwysing na die trieksterfiguur, Oompie, in Niggie (2002) wat ook heldersiende is. Dié konneksie blyk duidelik uit Willie se verklaring: "Daar's geen trieks aan nie" (Winterbach, 2003:19). Hierdie verband tussen die twee tekste word verder versterk wanneer Kieliemann se oë op dieselfde bladsy beskryf word as "smal Oosterse oë" (Winterbach, 2003:19), net soos Oompie se Oosterse oë.

In Karolina Ferreira is dit duidelik dat Winterbach hede en verlede jukstaponeer. In Niggie gebruik sy dieselfde tegniek, maar anders as in Karolina Ferreira waar daar net na die verlede verwys word, speel Niggie in die tydruimte van die Anglo-Boereoorlog af en word daar slegs implisiet kommentaar op die een-en-twintigste eeu gelewer. Winterbach verwys veral in Karolina Ferreira na die AngloBoereoorlog en die Britse verskroeide-aardebeleid: "Byna 'n honderd jaar gelede het Boer en Brit vrylik hier rondbeweeg. Hierdie provinsie was toe 'n betwiste gebied. Vroue, kinders en swartes is in groot stofwolke soos troppe diere hier rondgejaag. Die aarde is afgebrand" (Winterbach, 2003:21).

Adelia, wat uit Suid-Afrika geëmigreer het, beleef 'n oomblik van "behoort" wanneer sy opkyk na die panele (wat die paradys teenoor verskeie veldslae uitbeeld) in die eetkamer en besef: "lewers het ek 
ook deel aan hierdie geskiedenis" (Winterbach, 2002:140). Haar besef dat sy deel is van dié land se geskiedenis spreek boekdele oor elke mens in Suid-Afrika se aandeel aan die verlede.

Louise Viljoen merk in die inleiding van die 2003-uitgawe van Karolina Ferreira op: "Soos dikwels in die skrywer se romans, speel drome 'n belangrike rol in die verkenning van die menslike psige." 'n Verdere raakpunt tussen dié romans is die veerdroom van Jess. Hy droom van 'n voël met die "mees merkwaardige, helderkleurige, sellofaanagtige vere" (Winterbach, 2003:144), wat netjies aansluit by Niggie se tema oor die triekstervrou met die "besonderse verehoedjie", waarvan die dromende boer die "aanvalligheid" nie kan beskryf nie en wat in verskeie drome haar verskyning maak (Winterbach, 2002:8). Die triekstervrou se vere is ook helderkleurig en lyk soos dié van 'n berghaan (Winterbach, 2002:8), terwyl Jess s'n ook van 'n helderkleurige voël afkomstig is.

Buller se plan handel oor Esther Zorgenfliess wat die dorp, Steynshoop, in Natal besoek om haar neef Boeta tydens die begrafnis van Selene Abrahamson, 'n vrou wat hy liefgehad het, by te staan. Esther soek terselfdertyd ook haar vriendin, Fonny Alexander op, wat wreed aangerand is.

Die beskrywing van die Slag van Colenso "raam as't ware die vertelling deurdat dit aan die begin en die einde van die roman geplaas word. Vanuit die agternaperspektief wat die geskiedenis bied, is dit duidelik dat Buller se plan (waarop die titel sinspeel) misluk het" (Viljoen, 1999:1). Dié historiese gegewens is egter nog nader aan die werklikheid as wat die leser sou verwag. Steynshoop is anderkant Colenso geleë. Dit is weliswaar "ook 'n dorp met oorlogsgrafte, koeëldoppies uit die Anglo-Boereoorlog in die veld, 'n blokhuis, en 'n historiese Steynhuis" (Van Vuuren, 2000:2).

Andries Visagie verwys na die "oneerbiedige humor waarmee die groep uitgelese vroue in die Steynhuis improviseer op die publikasie van die briewe wat Boervroue aan hulle mans tydens die AngloBoereoorlog geskryf het" (Visagie, 1999:2):

My liewe Man, sê Alberta Bourgeois, kroep en brongitis is ons voorland. Een tamatie sou wondere verrig. Ek het 'n swam opgetel wat soms virulent is. Die kinders en die honde en die paar getroue bediendes wat nie gedros het nie, het wurms. Ek is onherkenbaar vermager. Ons wag elke dag om weggeneem te word. Ek word mal en sluit af met 'n hewige virulente soen, jou liefhebbende vrou. Die swam, sê Maria Wildenboer, het ek by ' $n$ besoekende Kakie opgetel aan wie ek ons laaste tamatie 
gegee het. Al brand hulle die huis af, en elke kosbare erfstuk daarin, ek sal nooit oorgee nie, sê Marta Vos (Winterbach, 1999:142).

Visagie let daarop dat Winterbach met dié wrang humor die vroue karakteriseer wat "kennelik nie meer leef in 'n era waarin heldeverering die enigste vorm van diskoers was waaroor Afrikaners van hulle Boerevoorsate mag praat nie" (Visagie, 1999:2). Dié roman van Winterbach sluit aan by die "afstandelike, ironiese blik waarmee Afrikaanse romanskrywers vanuit die jare negentig terugkyk op die Anglo-Boereoorlog" (Visagie, 1999:2).

'n Voorbeeld van "karnivaleske humor is die groep mans se bespiegeling by die oorlogsgrafte in die veld oor die bewussynsdroom van 'n eenvoudige Engelse soldaat in die Anglo-Boereoorlog" (Van Vuuren, 1999:5):

Jakes vra: Wat sou deur die loop van 'n enkele dag deur die gemoed van 'n ongeletterde Kakie gaan, van skouspelagtige sonsopkoms tot skouspelagtige sonsondergang? Heroïese gedagtes, sê Salmon, die een heroïese gedagte na die ander: Wat sal ek eet? Waar sal ek kak? Sal ek die dag oorleef? (Winterbach, 1999:31).

Die titel van die roman hou die herinnering aan die oorlog heeltyd in die bewussyn van die leser. Die karakters se name wys egter ook "terug na die 1899-1902 tydsgewrig" (Van Vuuren, 2000:11). 'n Voorbeeld hiervan is mnr. Mbulelo, die talking head na wie verwys word as "Siener van Rensburg redivivus". Dit is dikwels die geval dat "die stamboom van 'n karakter uitgelê [word] met verwysing na watter rol die oupa-grootjie in die Anglo-Boereoorlog gespeel het" (Van Vuuren, 2000:11).

Die magiese element van die waarsêer of "talking head" in Buller se plan hou verband met die Oompie-karakter se pratende kop wat op versterkwater bewaar word en oor 'n profetiese gawe beskik.

\section{Ouer intertekste}

Die ander tersaaklike intertekste vir Niggie is te vinde in dagboeke wat geskryf is tydens of kort ná die oorlog. In 'n meerdere mate word A.D.L se Woman's endurance (1904) gebruik en in 'n mindere mate word daar subtiel verwys na Deneys Reitz se Kommando: 'n Boeredagboek uit die Engelse oorlog (1912) [Commando. a Boer journal of the Boer War, 1929], asook Totius se Vier-en-sestig dae te velde. 
'n oorlogsdagboek (1977) en Jan F.E. Celliers se oorlogsdagboek 'n dagboek gevul met wag en passiwiteit.

Woman's endurance (1904) is gepubliseer onder die skuilnaam A.D.L. - die voorletters van die jeugdige dominee A.D. Lückhoff, wat vir twee maande vanaf 21 Augustus tot 24 Oktober 1901 as kapelaan by die Bethulie-konsentrasiekamp opgetree het. Hierdie dagboek, anders as die skrywersdagboeke van Celliers en Totius, bied historiese en psigiese insae in die traumatiese ervaring van lewe in 'n konsentrasiekamp. Dit is die skriftelike getuienis van die verskriklike gebeure wat daar plaasgevind het; gebeure wat anders saam met die gestorwenes vergete sou gewees het.

In Niggie is die karakter Kosie Rijpma gebaseer op ds. Lückhoff. Hy was ' $n$ "paar maande leraar in die konsentrasiekamp by Roodespruit" (Winterbach, 2002:83). Al wysiging is dat ds. Lückhoff by die Bethulie-konsentrasiekamp was. Japie Stilgemoed brei uit oor Kosie se verlede en noem dat hy eintlik "nege maande lank" (Winterbach, 2002:85) predikant in die konsentrasiekamp by Roodespruit was "voordat hy hier uitgekom het" (Winterbach, 2002:85). Gert Smal verduidelik (Winterbach, 2002:85): "Omdat hy van sy kop af gegaan het". In Lückhoff se geval was hy slegs twee maande by die Bethulie-konsentrasiekamp en het dié kamp verlaat na 'n senu-ineenstorting weens die oormaat begrafnisdienste wat hy moes hou.

Nog kommentaar oor Kosie en leidrade wat die interteks aktiveer, is "hy durf homself 'n predikant noem", "hy is lankal die kluts kwyt" (Winterbach, 2002:150) en hy vertel "oor die kinders wat die ewebeeld van muise was - dieselfde groot oë en dun ledemate" (Winterbach, 2002:106), wat dui op die ondervoede sieklike kinders in die konsentrasiekampe.

Niggie vertel dat sy 'n tyd lank "verpleegster in die Bethulie-kamp" was. Die feit dat sy in die Bethulie-kamp was, is 'n verwysing na Woman's endurance waarin ds. Lückhoff van sy ervaringe in dié kamp vertel. Hier is ook 'n moontlike verwysing na Johanna Brandtvan Warmelo se Het concentratie-kamp van Iréne (1905), waar sy verpleegster was tot sy ook siek geword het aan ooreising en trauma. In die Bethulie-kamp het Niggie gesien hoe vroue ly, dat daar geen genade vir enigiemand was nie, en hoe sy haar verwonder aan die vroue wat wou hê hulle "mans moet volhard in die stryd" (Winterbach, 2002:199). Sy draai geen doekies om wanneer sy haar uitspreek oor dié fenomeen nie (Winterbach, 
2002:199): "God help hulle - hulle bring hierdie saak ook oor hulle eie hoofde".

In Lückhoff se Engelse dagboek word vertel van 'n jong vrou, Betty Lotz (vgl. Lückhoff, 1904:20, 26, 29-31), wat in die kamp sterf. In Niggie verskyn sy as Bettie Loots, oor wie gereeld gedroom word (vgl. byvoorbeeld Winterbach, 2002:104, 158, 159, 163, 176, 183, $192,213,214,234)$. Sy was 'n meisie wat Kosie Rijpma op skool geken het en hy vra by geleentheid vir Ben en Reitz of hulle "belangstelling het om Bettie Loots se versies te lees" (Winterbach, 2002:104). In Lückhoff se dagboek vertel hy dat Betty Lotz, op hulle laaste ontmoeting, aan hom 'n versoek stel (Lückhoff, 1904:32): "Wanneer gaat, minheer dan mij stukkie lees uit die Bijbel"?

Ongelukkig is sy kort hierna, op 14 September 1901 oorlede en in 'n kombers begrawe (Lückhoff, 1904:32): "I hear Betty Lotz was buried yesterday in blanket; glad I was unaware it was she". Bettie Loots is ook in ' $n$ kombers begrawe (Winterbach, 2002:84), maar in teenstelling met Lückhoff was Kosie bewus dat hy haar ter aarde bestel (Winterbach, 2002:84). Tot haar dood het hy "daagliks 'n lewendige gesprek (met haar) gevoer" al was sy "teen die einde so swak en uitgeteer dat sy met moeite nog kon praat" (Winterbach, 2002:85). Hier lewer Winterbach kommentaar op die gruwelike werklikheid van die lewensomstandighede in die konsentrasiekampe. Lückhoff het dié begrafnis van Betty en sewe ander waargeneem, maar was onbewus dat sy een van die oorledenes was. Die versies waarna Kosie Rijpma verwys kan moontlik gekoppel word aan die Bybelversies wat die werklike Betty so graag voor haar dood wou aanhoor.

Kosie vertel die ander oor die onnodige dood van Bettie Loots: Sy was "agtien jaar oud (...) sy het aan die begin van haar lewe gestaan. Soos ' $n$ onbenullige kersie is haar jong lewe onder die haglikste omstandighede gesnuit. Soos dié van tientalle ander" (Winterbach, 2002:120-121). Kosie is geweldig deur haar dood beïnvloed en kon steeds nie van haar vergeet nie: "Hoe kan ek ooit die hoop én gelatenheid op haar gesig vergeet". Die dag van haar dood het hy geweet dat hy nie meer op God kan vertrou nie (Winterbach, 2002:121). Gert Smal bekyk Kosie takserend, asof hy wil sê: "Dis seker die dag wat jy van jou kop af gegaan het" (Winterbach, 2002:121).

Winterbach lewer kommentaar op ds. Lückhoff se geestelike toestand en wat hom moontlik tot 'n senu-ineenstorting gedryf het, deur Ben as spreekbuis te benut. Ben dink dat "van al die sterftes 
wat Kosie Rijpma daagliks in die kamp moes meemaak, was Bettie Loots se dood vir hom die keerpunt (...) [h] tet hy haar liefgehad en gedink dat dit onvanpas is"? (Winterbach, 2002:195).

Nog 'n ooreenkoms tussen dié tekste is die twyfel oor die bestaan van God weens die eindelose sterftes van die vroue en kinders. By een van die ontelbare begrafnisse dra ds. Lückhoff ter vertroosting 'n anonieme gedig voor oor die genadeloosheid van die dood (Lückhoff, 1904:59): "There is a Reaper whose name is Death, / Who with his sickle keen, / Cuts the bearded grain at a breath, / And the flowers that grow between".

Dié eksistensiële krisis word in Niggie weerspieël in die gesprek tussen Gert Smal en Kosie Rijpma, waar Gert getuig van God se foutlose plan en Kosie sy bitterheid daaroor uitspreek (Winterbach, 2002:160): "Ek wil my nog laat vertel dat God die welwillende vader is wat ons dink $\mathrm{Hy}$ is, vir wie die lot van elke sterfling iets is waaroor Hy hom buig." Die oorlog het van Kosie Rijpma 'n bitter mens gemaak en hy verklaar onomwonde (Winterbach, 2002:160): "Ek het dinge gesien waarvoor ek God en my medemens nie kan vergewe nie."

Lückhoff (1904:28) vertel in telegramstyl in sy dagboek van 'n onvergeetlike begrafnis: "Funerals - nine, I believe; great crowd; calamity; one grave short, and coffin had to be returned; women faint; consternation." In Niggie word dié verskriklike gebeurtenis byna verbatim oorvertel deur Kosie Rijpma. Hy vertel dat "daar op die dag waarop nege begrafnisse was, een graf te min was, en dat die kis teruggeneem moes word (...) [d]aar het konsternasie geheers, vroue het flou geval" (Winterbach, 2002:102). Die moontlike rede vir Winterbach se direkte vertaling van hierdie gebeurtenis is om die atmosfeer van hulpeloosheid, dood en chaos wat meer as 'n eeu gelede in dié konsentrasiekamp geheers het, oortuigend te weerspieël deur die konstruksie van taal.

Nóg 'n ooreenkoms tussen dié tekste is die kapelaan se woede teenoor die mense wat soos agies om 'n tent vergader wanneer iemand sterf. Kosie het hulle "verjaag om die sterwende 'n paar laaste oomblikke van vrede te gun" en hulle skerp aangespreek: "Vanwaar hierdie aaklige aangetrokkenheid tot die sterfbed?" (Winterbach, 2002:95). Hierdie insident is presies dieselfde in Woman's endurance (Lückhoff, 1904:29): "Saw crowd (hateful) round 34 (number of tent) (...) strong words to crowd. This horrible attractiveness of a deathbed! Where does it originate?" 
$\mathrm{Na}$ slegs twee maande in dié emosioneel uitputtende omstandighede van lewe in 'n konsentrasiekamp, het die kapelaan uiteindelik geestelik versteurd geraak en aan "mental delusion" gely (Lückhoff, 1904:67). Hy vertel in die slot van sy dagboek hoe hy dae lank aanhoudend die begrafnisformulier op sy siekbed voorgedra het. Hierdie "kompulsie (is) klaarblyklik ingegee deur die honderde dooies wie se begrafnisse hy in hierdie periode moes waarneem" (Van Vuuren, 2002:89).

Ná die oorlog het P.L.A. Goldman (aangehaal in Pretorius, 1985:57) amptelik vasgestel dat 27927 Boere in die konsentrasiekampe gesterf het: 26251 vroue en kinders (waarvan meer as 22000 onder die ouderdom van 16 jaar was), en 1676 mans bo 16 jaar, waarvan 1421 bejaardes was.

Deneys Reitz, seun van Francis William Reitz (1844-1934) die oudpresident van die Oranje-Vrystaat en op daardie tydstip Staatsekretaris van Transvaal, was aan die begin van die oorlog sewentien jaar oud.

Die mees opvallende ooreenkoms tussen Commando (1929, heruitgawe 1932) en Niggie is die lang reis te perd wat in albei tekste beskryf word. Die karakters in Niggie reis deur die landskap om 'n boodskap af te lewer (Winterbach, 2002:14-34) en Reitz se groep probeer weer by hulle leier, Smuts, aansluit nadat hulle van mekaar tydens 'n geveg geskei is. In teenstelling hiermee het kommandant Servaas Senekal sy soektog na Smuts laat vaar (Winterbach, 2002:12).

In Reitz se joernaal is daar 'n hele hoofstuk, "A Long Trail" (Reitz, 1932:258-276) oor die tog te perd om weer vir Smuts in te haal. Reitz (1932:257) erken mismoedig: "difficult weeks were to elapse before we found them again". Die kommando van Willem Boshoff se ondervinding op dié reis is ook een van uitputting en uitdagings. Hulle word oorval deur 'n geweldige stofstorm en moet noodgedwonge teen die flanke van hulle perde hurk vir beskerming. Hulle enigste proviand is 'n bietjie "louerige water" (Winterbach, 2002:29) waarmee hul skaars hul lippe natmaak en hul enigste kos is "blare" wat Ben by hom het (Winterbach, 2002:29).

Reitz se groepie ontmoet 'n man met die naam Cordier, wat in "a cluster of huts" woon. Hulle het die hutte genader omdat hulle gedink het om natives (Reitz, 1932:272) daar te vind om as gidse te gebruik. Daar is verskeie ooreenkomste tussen Cordier en die Oompie-karakter in Niggie. Een van die teenstellings is egter dat 
Oompie in die klowe op sy eie woon, alhoewel dit ook in 'n hut is (Winterbach, 2002:43) terwyl Cordier en sy gesin in hutte bymekaar woon.

Cordier is ' $n$ "shaggy giant in goatskins [who] appeared and spoke to us in strange outlandish Dutch" (Reitz, 1932:273). Dié bokvelle en eienaardige taal herinner ook aan Oompie. Celliers kom op 14 Januarie 1902 'n kommandolid teë wat sy voos-gelapte klere vir velle verruil het: "Ik heb daar juist Robinson Crusoe ontmoet - een oom met een compleet pak kleeren uit bokkenvellen vervaardigd met de haaren naar buiten" (Celliers, 1978:333). Dié verwysing dui ook op 'n ooreenkoms met Oompie.

Cordier, is 'n wit man en leef met sy vrou en 'n "brood of half-wild children, in complete isolation from the outside world" (Reitz, 1932:273). "He knew all about us" (Reitz, 1932:273) word in Oompie se stelling geëggo dat hy geweet het hulle (Gert Smal, Ben en Reitz) kom (Winterbach, 2002:43). Hy het van hulle teenwoordigheid geweet, want sy seun "had stalked us and carefuly noted our number and the language we spoke" (Reitz, 1932:273). Cordier se seun toon in hierdie opsig 'n ooreenkoms met Gert Smal se Seun wat Ben en Reitz by die rivier afloer.

Hulle is ontvang met "uncouth but sincere hospitality, and we applied ourselves gratefully to the goats' meat, milk, and wild honey that were placed before us" (Reitz, 1932:273). Cordier "told us that no British troops had ever penetrated this fastness and that we were the first Boers to do so. He had heard vaguely of the war, but his knowledge of the events of the last two years was scanty" (Reitz, 1932:273). Oompie het self ook byekorwe, koeie en skape (Winterbach, 2002:44) en die Britse troepe het klaarblyklik ook nie tot by sy tuiste deurgedring nie.

Totius se oorlogsdagboek, Vier-en-sestig dae te velde: 'n oorlogsdagboek is in 1977 in beperkte oplaag (slegs 300 eksemplare) in faksimilee-vorm uitgegee. Dié dun boekie dek slegs twee van die sewe maande wat hy as Kaapse rebel in die veld deurgebring het, vanaf 12 Oktober tot 14 Desember 1899. Sy dagboek eindig ná die slag van Magersfontein (Du Toit, 1977:51): "Een lykrede gehouden by een gat van 25 lyken, vragende dat de vrede komen zal als een donderslag uit den hemel, onder zijn geween." Nie lank hierna nie het sy swak gestel ingegee en moes hy eers weg na Burgersdorp om te herstel. 
Totius het op aanvraag van sy verloofde Marie Postma 'n dagboek begin. Jan F.E. Celliers het ook 'n dagboek gehou (Oorlogsdagboek van Jan F.E. Celliers, 1899-1902, 1978, heruitgawe 2000) van sý tyd in die oorlog, waarin hy sy vrou soms direk aanspreek. In hierdie opsig hou Totius en Celliers se dagboeke as oorlewingsmeganisme verband met Niggie en die karakter van die boer wat verlang na sy oorlede vrou. In elke geval is elkeen van die mans wat in die fokus staan gekoppel aan 'n vrou.

Een van die klein, dog noemenswaardige ooreenkomste tussen Totius en Celliers se dagboek is die melding van 'n soort vetkoek wat die Boere in die veld gemaak het, 'n "stormjager" (Du Toit, 1977:28). Celliers meld dat aangesien die kommando's nie toegang gehad het tot alle bestanddele nie, het hulle hulle eie resepte ontwikkel. Een van die gunsteling resepte was dié van "stormjagers". Dit word gemaak uit "een mengsel van meel en water met wat bakpoeder. In een pot, op het vuur, die eenige kopjes gesmolten vet bevat, wordt het deeg bij lepelsvol ingebracht; elk lepelvol rijst uit tot een bruin broodje dat zeer goed smaakt" (Celliers, 1978:91).

Dié skynbaar onbenullige feit is deel van die Boerekultuur wat vergete geraak het, soos die geval met die meeste Boererate. Die feit dat ' $n$ bekende volksdigter ' $n$ eeu gelede hom besig gehou het "met vet uitbraden en stormjagers maken" (Du Toit, 1977:35) en dié alledaagse taak vir die nageslagte in sy dagboek bewaar het, is tog op geskiedkundige en literêre vlak van belang. In Niggie is daar 'n verwysing na roosterkoek (Winterbach, 2002:111) - ook 'n tradisionele soort broodjie wat op die vuur gemaak is. Winterbach is in Niggie besig om die geskiedenis in en van taal vas te lê, nie net deur Boererate en ander merkwaardighede nie, maar ook taboewoorde wat rassisties van aard is, soos dié wat "kaffer" as stam het (Winterbach, 2002:29-30).

Op 13 November gaan Totius by die krygskommissaris aandete geniet en hy verklaar daarna dankbaar (Du Toit, 1977:37): "Wat eene heerlikheid was het weer na lange maanden aan een tafel te zitten." Totius oordryf 'n tikkie hier, want tot op dié datum is hy slegs één maand in die veld. Jan F.E. Celliers is nog 'n kommandolid wat beïndruk word deur verfyndheid. In sy geval is dit 'n vaas pragtige rose op die eetkamertafel in die huis waar hy oornag het (Celliers, 1978:299). In Niggie is Reitz, soos Totius en Celliers, verwonderd oor die prag van 'n huislike maal met glasborde en behoorlike eetgerei. Die eerste aand by Niggie is hulle aanvanklik oorweldig "deur die opset van die maaltye - die wit tafeldoeke en die eetgerei, 
die skottels waaruit die kos opgeskep word"; al is die voedsel "karig het die maaltye iets wellewends en beskaafs, wat dit op kommando lank nie meer gehad het nie" (Winterbach, 2002:196).

\section{Meer resente intertekste}

Chris van der Merwe merk op dat daar twee teenoorgestelde uitbeeldings van die Anglo-Boereoorlog is, wat skakel met "verskillende reaksies op die krisis van die hede" (Van der Merwe 1998:2). In die eerste vertel die skrywer oor die oorlog wat algemeen beskou is as die mees "heroïese tyd in die geskiedenis van die Afrikaner om sodoende verlore selfrespek te herwin, en moontlik ook wys op die onreg wat teen die Afrikaners gepleeg is dat die Afrikaners nie die uitsluitlike skuldiges van die geskiedenis is nie" (Van der Merwe, 1998:2). Die tweede uitbeeldingsmoontlikheid is om die "heroïek van die verlede te relativeer en te dekonstrueer as deel van die konfrontasie met en verwerking van die skuld van die verlede" (Van der Merwe, 1998:2). Op soek na generaal Mannetjies Mentz val in die tweede kategorie.

Die verhaal fokus op die optrede van 'n geheimsinnige Boeregeneraal, Mannetjies Mentz, en sy kommando in die Vrystaat wat wraak neem teen Engelse soldate wat Boere gevange neem, maar ook teen Boere wat, volgens hulle, te maklik oorgee. Dié roman beïndruk en word deur talle as 'n magnum opus beskryf, omdat dit 'n tema aanraak wat nog nie vantevore in Afrikaans só benader is nie, naamlik die sogenaamde Wraakkommando's.

Niggie kan in 'n sekere opsig as die vroulike teenhanger van die manlike Mannetjies Mentz gelees word. Die ruimte in Niggie is passief teenoor Mannetjies Mentz se aksie en geweld. Waar Mentz met die vroue se betoog begin en met die mans s'n eindig, is Niggie heeltemal die teenoorgestelde, met die mans wat die betoog vir die meerderheid van die teks oënskynlik oorheers en die vroue wat slegs in die laaste paar hoofstukke 'n spreekbeurt kry.

Mannetjies Mentz is soos Niggie 'n verwikkelde en meervlakkige roman. Monica Jacobs lewer kommentaar: "Op die oppervlak handel die verhaal oor gebeure in en direk na die Boereoorlog, maar dit kan ook gelees word as implisiet verwysend na die wandade tydens die apartheidstydperk en die gebeure daarna" (Jacobs, 1998:1). Die verhaal beweeg ook op mitologiese, godsdienstige en metafisiese vlakke" (Jacobs, 1998:1), soos in die geval van Niggie. By albei is daar slim kreatiewe verwerking van historiese feite om 'n "nuwe" realiteit en bewussyn van die verlede te skep. 
Soos in Mannetjies Mentz, is daar in Niggie ook 'n generaal wat drosters in 'n lokval lei, vroue wat lank in 'n klofie oorleef het, en 'n meditasie oor die aard van geskiedenis.

Die magiese element van die drekgod sluit aan by die Oompiekarakter in Niggie, wie se magiese kragte afkomstig is van die Bose. Daar is egter in albei romans hoop wat as teenmiddel teen die Bose magte inwerk. In Niggie is die verehoedjie 'n simbool van hoop en kreatiwiteit (sien John, 2004:39) en in Mentz is Jan Witsie en Charlie White, "'wit' simbole van goedheid en die stryd teen kwaad (en) oorwin uiteindelik Mentz se kommando" (Van der Merwe, 1998:5).

Die sterk rol wat godsdiens in die Boere se lewens gespeel het, word in Mentz (soos ook in Niggie) weerspieël: "Hulle sterkte lê dikwels daarin om die een of ander Moses se arms in die laer omhoog te hou. Behoede die offisier wat hulle uit die biduur by die laer na die linie wou boender!" In dié opmerking is 'n ironiese toon te bespeur, want terwyl dié manne bid, is daar ander wat met "die roer in die hand sneuwel" (Van der Merwe, 1998:152).

Die ideologie van heldhaftige stryders in die Anglo-Boereoorlog word verdraai deur hierdie twee kommando's se onderskeie optredes. In Mentz se geval is dit die gruwelike wandade wat gepleeg word teen hulle eie mense, maar ook die wreedheid van hulle aksies teenoor hulle eintlike vyand, die Engelse (vgl. byvoorbeeld Van der Merwe, 1998:75, 77, 81).

Die Wraakkommando is 'n klein groepie wat weggebreek het uit die Boeremagte en verteenwoordig nie alle kommando's se aksies tydens die Anglo-Boereoorlog nie. Tog word Mannetjies Mentz ('n denkbeeldige historiese figuur) uit die geskiedenisbladsye gewis oor sy skandelike gedrag. Dit blyk ook die geval te wees met generaal Bergh en sy kommando in Niggie, aangesien Reitz "alle dokumente (...) alle amptelike lyste wat vrygestel word oor gevangenes" nagaan, maar nooit weer die name van enige van Bergh se kommando vind nie (Winterbach, 2002:250).

Ons oorlog (2000) van Klaas Steytler is die verhaal van die Havenga-Steytler-familie se ervarings in die Anglo-Boereoorlog. In die voorwoord verduidelik Nico, Steytler se seun, dat dit wat hulle persklaar sou maak ná sy vader se dood, "die familiestorie - 'n persoonlike storie, sy storie" sou wees (Steytler, 2000:i). Dié persoonlike storie word egter ook die leser se storie deur die noue betrokkenheid met hierdie lewensgrootte karakters se lewens. 
Hierdie roman se titel is van pas en hierdie gebeurtenis word werklik verpersoonlik tot "óns oorlog".

Die unieke van Steytler se teks wat in Niggie ook neerslag vind, is die betreding (soos in Ons oorlog) of bloot die poging tot kontak met 'n geliefde (soos in Niggie) in die doderyk om versoening te bewerkstellig. In albei hierdie romans kry hierdie proses 'n psigoanalitiese aspek, wanneer die karakters nie slegs die doderyk of skaduryk betree nie, maar terselfdertyd hulle binnekamer om die gebeure van die verlede met die hede te versoen.

Reitz poog om met sy oorlede vrou vrede te maak deur die skaduryk van die dood, of ten minste die ruimte tussen die wêreld van die lewendes en die wêreld van die dooies te betree. In Steytler se roman betree Niemand egter werklik die doderyk en vaar oor die Swart Rivier na die anderkantste oewer.

Niemand wat gelykluidend aan Niemann in Coetzee se Op soek na generaal Mannetjies Mentz is, kan dui op 'n soort allemans-argetipe wat in die Afrikaanse letterkunde ontstaan het. Niemand, een van die nageslag van dié wat deur die Anglo-Boereoorlog geveg het, vra: "Hoekom moet ek in die Onderwêreld afsak voordat ek huis toe kan gaan?" (Steytler, 2000:1). Dié "Onderwêreld" waarna verwys word skakel met Oompie se jas waarmee dit lyk of hy "onderwater" (Winterbach, 2002:45) daarmee geswem het. In albei dié gevalle word moontlik na Freud se teorie oor die werking van die onderbewuste verwys.

Etienne Leroux was 'n belangrike vormende invloed op die skrywer Ingrid Winterbach/Lettie Viljoen. Hulle briefwisseling het moontlik as inspirasie vir Leroux se 18-44 (1967) gedien. Winterbach gebruik Leroux se benadering tot die Anglo-Boereoorlog, soos in Magersfontein, O! Magersfontein (1976) intertekstueel as kreatiewe stof op die vlak van tegnieke en ook ironisering van die "vleklose" verlede van die Afrikaner.

Leroux het sinies oor die historiese aspek van Magersfontein (...) opgemerk: "Ek is geen historikus nie, want ek haat as romantikus alle gegewe wat deur navorsers vasgepen is. Ek verkies die legende" (Leroux, 1980:1). Hierdie stelling suggereer dat kreatiwiteit nie logies en ordelik is nie, maar eerder a-logiese spronge maak. Leroux se werk, soos Winterbach s'n, is sterk visueel deur sy gebruikmaking van metafore en beelde. Leroux se roman kan oorwegend Jungiaans gelees word deur sy gebruik van argetipes, 
veral uit die Suid-Afrikaanse geskiedenis en samelewing. Winterbach is egter meer ingestel op Freud, veral ten opsigte van drome.

Die legende van Magersfontein is seker die toppunt van ironie in die Anglo-Boereoorlog. Leroux vermeld dat een van die trekpleisters vir dié projek juis die ironie van dié Boere-oorwinning in sulke verwarrende en tragikomiese omstandighede en die "ironical function of historical events" was (Leroux, 1980:1). Hierdie siening kom ook in die roman voor, wat die ironie verder verhoog (vgl. Leroux, 1976:28). Leroux is ook aangetrokke tot die voorspelling wat dié gebeurtenis vir die toekoms ingehou het: "Die loopgrawe van Magersfontein was 'n kosmiese voorspelling van miljoene wat in loopgrawe in die Eerste Wêreldoorlog sou gesterf het" (Leroux, 1980:1).

In Niggie merk Gert Smal oor dié veldslag op: "Cronjé het sy oorwinning by Magersfontein aan De la Rey te danke (...) sonder sy advies het die ou lelik afgekak" (Winterbach, 2002:55). Dit is die enigste verwysing na Magersfontein in Niggie. Hierdie veldslag speel dus nie ' $n$ prominente rol in die roman nie, maar die ironie daarvan vind wel weerklank in Winterbach se kommentaar op die oorlog.

Leroux se opmerking skakel met Winterbach se preokkupasie met die Anglo-Boereoorlog in haar oeuvre: "Dis die vloek van die geskiedenis dat die verlede nie kan sterf en hom losmaak van die hede nie. Hoe kan die mens ooit vry wees as daar geskiedenis is" (Leroux, 1976:33).

\section{Die funksie van intertekstualiteit en historiografiese metafiksie}

Hans Heese maak die belangrike opmerking dat daar uit "Afrikanergeledere vóór die Anglo-Boereoorlog geen opgeleide geskiedskrywers" was nie (Heese, 1992:86). Daar het eers na die afloop van die Anglo-Boereoorlog en uniewording 'n reeks Afrikaanse geskiedskrywers na vore getree. Daar moet egter melding gemaak word van 'n pionierswerk wat in 1877 verskyn het, naamlik S.J. du Toit se Di geskiedenis van ons land in di taal van ons volk (1847-1911).

Die Suid-Afrikaanse geskiedenis begin volgens bogenoemde gegegewe eers ná die Anglo-Boereoorlog, aangesien geskiedskrywing eers op daardie tydstip begin het. Dit verklaar Winterbach se stelling dat dié gebeurtenis in ons geskiedenis die verste is wat 
die Afrikaanse kollektiewe geheue terug strek (onderhoud met Manie de Waal, et al., 2004:4). In Niggie verweef sy feit met fiksie en deur hierdie proses lewer sy striemende kommentaar op die verlede en hede.

Alhoewel geskiedenis en fiksie voorkom as teenoorgesteldes, verduidelik Dominick LaCapra dat geskiedenis en fiksie nie noodwendig gereduseer kan word tot binêre opposisies nie: "the interaction or mutually interrogative relation between historiography and art (including fiction) is more complicated than is suggested by either an identity or a binary opposition between the two" (LaCapra, 2001:15).

In Niggie word die tradisionele heldeverering van strydvegters ondermyn. Viljoen merk op dat die gesprekke in die opvangskamp "verskillende en opponerende sienings oor die oorlog" gee en gevolglik in dié roman 'n belangrike rol speel: "In die proses onthul die karakters hulself én die geestestemming van die vroeg twintigste eeu (...) [h]iernaas roep die uitvoerige gebruik van volkswoorde (ook dié waarin raspejoratiewe voorkom) 'n vervloë tyd op" (Viljoen, 2003).

Pakendorf (2002) deel Viljoen se entoesiasme oor Winterbach se roman: "Op een vlak gee Niggie 'n realistiese naby-opname van die onbestendige lewe van die Boeremagte teen die einde van die oorlog" en op 'n "ander vlak word 'n mens telkens getref deur die poëtiese krag waarmee die kleure en kontoere van die wisselende landskap besweer word". Venter (2002:7) is nie so liries oor dié roman soos sy eweknieë nie: "Niggie is 'n verbeeldingryke roman, die vaal kolle ten spyt. Dit gee 'n blik op die Anglo-Boereoorlog wat ver verwyder staan van die heroïese. Dis 'n boek van verlies, van stukkies bymekaarmaak en verder probeer lewe." Human poneer (2002:28):

Die gereserveerde mineurtoon, eerlike maar subtiel ondermynende blik op die oorlog, asook die blootlegging van die mens in al sy weerloosheid, maak van Niggie 'n uiters geslaagde besinning oor die kortstondigheid van menslike geluk en die fisieke en psigologiese letsels wat oorlog laat.

Daar is 'n paar karakters soos Willem Boshoff wat die Boerekrygers se aksies vurig verdedig. In teenstelling met Willem is daar egter Gert Smal wat rebels optree en lasterlik met die reputasie van sy volk se kommando's omgaan. Dit is egter deur die optrede van veral Smal se groep dat Winterbach kritiek lewer op die geykte opvatting oor die Boere se stryd tydens die Anglo-Boereoorlog. Daar is 
byvoorbeeld in Niggie voorbeelde van dagga-misbruik, pogings om die tyd te verdryf, die versteurde gemoedstoestand van kommandolede en 'n antiheroïse siening.

Dagga wat soms aangewend word vir medisinale doeleindes, word in Niggie gerook vir ontspanning en seker ook ontvlugting uit die vervelige alledaagse. Reeds vroeg in die roman word melding gemaak van kommandant Servaas Senekal se swakhede. Hy het 'n swakheid vir "vrouevlees en enige gepaardgaande vorm van beneweling: hetsy uit die bottel, óf aan die hand van die kruid tabak of andersins" (Winterbach, 2002:17). Dié swakhede, naamlik drank en dagga, word veral gebruik deur Gert Smal en Ruieben (vgl. byvoorbeeld Winterbach, 2002:63, 68, 78-80, 82). Die laaste keer wat dagga genoem word, is in een van Ben en Reitz se woordspeletjies: '“Daggabossie,' wys Ben uit, 'Gert Smal se geliefkoosde kruid"” (Winterbach, 2002:172).

Winterbach se ironiese humor blyk uit die debatte tussen Willem en Gert Smal. Willem wat altyd patrioties optree, noem dat ten minste een van die helde van die verlede tog sy sout werd was, naamlik Cronjé, "die leeu van Afrika", terwyl Gert Smal hom degenereer tot die "skaap van Afrika" (Winterbach, 2002:167).

Winterbach laat nie na om op ironiese wyse kommentaar te lewer op die ideaal van Afrikanernasionalisme wat gedeeltelik gebou is op die Boerekrygers se heldhaftige veldslae teen die Britte nie. Generaal Bergh se kommando, tesame met Gert Smal se groep insluitend Ben, Reitz, Willem en Abraham poseer vir 'n foto. Die manskappe sien keurig daar uit met "windmaker hoede" "gepoetste laarse en netjiese rybroeke", geweer en bandelier en hulle hou hul "gelapte en erg verslete klere so goed moontlik buite sig" (Winterbach, 2002:137). Die foto is geneem, "hulle beeld is bewaar vir die nageslag" en dit is uiters ironies dat na dié groep se foto eendag gekyk sal word as 'n voorbeeld van die bittereinders in die verskriklikste oorlog in die Suid-Afrikaanse geskiedenis.

Wanneer gepraat word oor die "stryd" wat "tevergeefs" was, maar sal voortduur tot in die lewens van die "kinders se kinders" (Winterbach, 2002:93) het ons ook met eietydse, ouktoriële kommentaar te make, en is die uitspraak ook betekenisdraend as profesie of interpretasie van die hede en die toekoms. Soos in Karel Schoeman se Verkenning (1996), toon Niggie (2002) 'n betrokke element, al is dit hoe onderbeklemtoon, en 'n historiografiesmetafiksionele inslag, wat ook in die intertekstuele spel met eietydse tekste weerspieël word. 
Niggie bring vernuwing met eksperimentele tegnieke, en 'n deelselegiese, deels-humoristiese konfrontasie met die moontlike ondergang van Afrikaans en die Afrikaner as groep. Dié stelling word beklemtoon deur Ben se woorde in die wetenskaplike lesings: "Groepe wat minder aanpasbaar is, sterf uit" (Winterbach, 2002:147).

Oompie wat in die toekoms kan sien, openbaar aan Ben en Reitz dat die oorlog binnekort sal eindig, maar dat dit nog nie die einde van die stryd is nie: "Die einde van die stryd sal nie afgelope wees in julle lewens nie, en nie in julle kinders se lewens nie, en nie in julle kinders se kinders se lewens nie" (Winterbach, 2002:93). In Oompie se opinie, net soos met Ben en Reitz, was die stryd tevergeefs (Winterbach, 2002:93). Dié eietydse kommentaar is profeties van die toekoms en word fyn verweef in die betoë van Winterbach se karakters in die esoteriese intellektuele wêreld wat sy vir hulle geskep het.

LaCapra wys daarop dat "a radically constructivist position" verdedig word deur belangrike literatuurteoretici soos Hayden White (1992) en Frank Ankersmit (in Zammito, 1998) wat aanvaar: "the distinction between historical and fictional statements [is] on the level of reference to events but question it on structural levels" (LaCapra, 2001:8).

Verder noem LaCapra daar is "an identity or essential similarity between historiography and fiction, literature, or the aesthetic on structural levels" en dat hulle klem lê op "the fictionality of structures in all these areas" (LaCapra, 2001:8). White en Ankersmit verklaar historiografie as "a closed window so stained by one set of projective factors or another that, at least on a structural level, it reflects back only the historians' own distorted image" (LaCapra, 2001:8).

Dori Laub se kommentaar op historiografie en fiksie vul dié siening aan, en haar insig is ook toepaslik op Winterbach se Niggie: "That history subverts its witnessing and turns out to be linguistically involved with fiction does not prevent the fiction, however, from functioning historically and from having deadly factual and material consequences" (Laub aangehaal in Van Vuuren, 2002:88).

Die wrede realiteit van oorlogvoering tree sterk op die voorgrond wanneer die kommando om die vuur praat van gruwelike dade wat tydens die oorlog gepleeg is. Reitz onthou nog die "kranksinnige gebrabbel (...) van 'n kêrel wat langs hom deur 'n granaatskerf 
getref is wat sy harsings blootgelê en sy oë weggeskeur het" by Droogleegte (Winterbach, 2002:131). Oom Honne vertel van die "skande van Derdepoort", hoe die "Khama-Kaffers - bondgenote van die Engelse en onder aanvoering van 'n Engelse offisier die dorpie onverwags (...) oorval het (...) van die oneer wat die vroue aangedoen is. 'Een arme meisiekind is deur vier Kaffers vasgehou terwyl nege Kakies hulle skandelike bedryf volbring het'" (Winterbach, 2002:131). Die karakters se lewens en ervarings getuig van die afskuwelikheid van die oorlog soos Niggie se huis wat deur Kakies afgebrand is en die vroue wat weggeneem is na die konsentrasiekampe (Winterbach, 2002:182-183).

Die vergeefsheid van oorlog en die streng gevoelens van sowel Boer as Brit se kant oor drosters word uitgedruk deur Reitz se wil om weg te kom uit hulle ongemaklike situasie by Gert Smal se groep, maar soos Ben hom herinner is hulle nie neutrale burgers nie en "[m]ens veg óf vir die Boere óf vir die Engelse - nie een van die twee kante het genade met drosters nie!" Ben is bereid om in die kamp vir gevegsongeskiktes te bly, want sodoende het hy nie meer deel aan die "bloedvergieting, aan die slopende vergeefsheid van die kommandolewe nie" (Winterbach, 2002:156). Dié stelling reflekteer Celliers se uitspraak oor dieselfde saak in sy oorlogsdagboek (Celliers, 1978:316).

Die kontroversiële vraag word in die teks gevra, naamlik of die oorlog dit werd was. Reitz opper die gedagte: "As die loop van die oorlog voorsien was - hoeveel van ons sou besluit het die prys is te groot om te betaal"? Hy berou dat hy ooit aan die oorlog deelgeneem het: "Daar is beelde wat ek vandag nie uit my kop kan kry nie (...) [a]l die dooies. Wie sou kon dink dat dit so 'n slagting sou wees" (Winterbach, 2002:161).

Van Jaarsveld (1992:123) se stelling sluit hierby aan: "Die verlede is dikwels uit gesigspunte van die hede ontsluit."

\section{Slot}

Hierdie roman het 'n ingrypende impak op die leser 'n eeu na die oorlog, want dit hanteer postkoloniale kwessies en verknorsings, soos 'n verbrokkelende identiteit, sowel as die moontlike ondergang van die Afrikaanse taal en kultuur wat deur die nasate van dié wat in die Anglo-Boereoorlog betrokke was, ondervind word. In haar verwerking van die verlede versoen sy haar met die hede. Winterbach konfronteer moeilike Suid-Afrikaanse onderwerpe soos rasseverhoudings, rassisme, die verhouding met die land, die moontlike 
taaldood van Afrikaans, geslagsverhoudings, die rol van die bonatuurlike en die onderbewussyn in die alledaagse lewe (in die gedaante van die trieksterfigure en drome), om maar 'n paar te noem.

Ten slotte is die intertekstuele verwerking van meer resente tekste met 'n Anglo-Boereoorlogtema in Niggie 'n aanduiding van die meerdimensionele aard van hierdie roman. Daar word egter ook deur hierdie intertekstuele spel, soos in die geval van verskeie resente Anglo-Boereoorlogromans, ideologiese kommentaar gelewer op die verlede. Die belangrikheid van dié oorlog vir die vorming van 'n Afrikaanse identiteit kan nie misken word nie. Dit is duidelik uit die talle romans wat oor die Anglo-Boereoorlog, 'n eeu na die afloop daarvan op die boekemark verskyn, dat die teikenleser Afrikaans is.

Uit die subtiele jukstaponering van die Afrikaanse taal, kultuur en omstandighede van 'n eeu gelede met die tydgenootlike gegewens, via die intertekstuele spel, suggereer Winterbach in Niggie taalregressie en -verarming, en die "bedreiging van 'n spesie" genaamd homo Africanensis. Dié suggestie word egter besonder onderbeklemtoond aangedui - slegs merkbaar vir die leser wat moeite doen om die "oop plekke" in te vul, daar waar die raakvlak tussen "toe" en "nou" is ...

\section{Geraadpleegde bronne}

BRANDT-VAN WARMELO, J. 1905. Het concentratie-kamp van Iréne. Amsterdam: HAUM.

BRINK, ANDRÉ. 1998. Duiwelskloof. Kaapstad: Human \& Rousseau.

CELLIERS, JAN F.E. 1978. Oorlogsdagboek van Jan F.E. Celliers, 1899-1902. Pretoria: Raad vir Geesteswetenskaplike Navorsing.

CELLIERS, JAN F.E. 2000. Oorlogsdagboek van Jan F.E. Celliers, 1899-1902. Stellenbosch: Genealogiese Instituut van Suid-Afrika.

COETZEE, CHRISTOFFEL. 1998. Op soek na generaal Mannetjies Mentz. Kaapstad: Queillerie.

DE WAAL, MANIE, DIEDERICKS-HUGO, CARINA, DU PLESSIS, CLINTON V. \& VAN VUUREN, HELIZE. 2004. Ingrid Winterbach, wie se roman Niggie met die Hertzogprys bekroon is, word deur Ons Paneel onder hande geneem. http://www.litnet.co.za Datum van gebruik: 15 Jun. 2004.

DU TOIT, J.D. 1977. Vier-en-sestig dae te velde: 'n oorlogsdagboek met aantekeninge deur V.E. d'Assonville. Kaapstad: Tafelberg.

DU TOIT, S.J. 1895. Di geskiedenis van ons land in di taal van ons volk. Paarl: D.F. du Toit.

HEESE, HANS. 1992. Slawerny in die Afrikaanse geskiedskrywing. (In Bredekamp, H.C., red. Afrikaanse geskiedskrywing en letterkunde: verlede, hede en toekoms. Bellville: Universiteit van Wes-Kaapland se Instituut vir Historiese Navorsing. p. 86-103.) 
HUMAN, THYS. 2002. Die enigmatiese niggie ken baie trieks. Rapport: 1, 28 Des.

JACOBS, MONICA. 1998. Wreedheid en gruwels van geskiedenis verwikkeld belig. http://www.upe.ac.za/afned/mentz.htm Datum van gebruik: 6 Feb. 2005.

JOHN, PHILIP. 2004. Meer dydelikhyt oor die punch en die vis: 'n vergelyking van Niggie, Daar's vis in die punch en Eilande. Literator, 25(1):23-46.

KRISTEVA, JULIA. 1969. Sémiòtiké: recherches pour une sémanalyse. Paris: Seuil.

KRISTEVA, JULIA. 1980. Desire in language: a semiotic approach to literature and art. Ed. by Leon S. Roudiez; translated by Thomas Gora, Alice Jardine \& Leon S. Roudiez. New York: Columbia University Press.

LACAPRA, DOMINICK. 2001. Writing history, writing trauma. Baltimore: John Hopkins University Press.

LEROUX, ETIENNE. 1973 [1967]. 18-44. Kaapstad: Human \& Rousseau.

LEROUX, ETIENNE. 1976. Magersfontein, O! Magersfontein. Kaapstad: Human \& Rousseau.

LEROUX, ETIENNE. 1980. Hoekom skryf 'n skrywer oor Magersfontein en hoekom Magersfontein, O Magersfontein? Tydskrif vir Letterkunde, 1 Februarie. Herdruk op http://afrikaans.be Datum van gebruik: 6 Feb. 2005.

LÜCKHOFF, A.D. 1904. Woman's endurance. Cape Town: S.A. News.

MÜLLER, PETRA. 2003. 'n Boek waarmee 'n mens moet saamleef soos 'n stuk vuur. http://www.litnet.co.za Datum van gebruik: 19 Jun. 2004.

PAKENDORF, GUNTHER. 2002. Hede word verlede. Die Burger: 24 Nov. Herdruk op http://www.landbou.com/Die_Burger/Boeke Datum van gebruik: 6 Feb. 2005.

PRETORIUS, FRANSJOHAN. 1985. Die Anglo-Boereoorlog, 1899-1902. Kaapstad: Don Nelson.

PRETORIUS, FRANSJOHAN. 1999 Kommandolewe tydens die AngloBoereoorlog, 1899-1902. Kaapstad: Human \& Rousseau.

REITZ, DENEYS. 1912. Kommando: 'n Boere-dagboek uit die Engelse oorlog. Kaapstad: HAUM.

REITZ, DENEYS. 1932 [1929]. Commando: a Boer journal of the Boer War. London: Faber \& Faber.

SCHOEMAN, KAREL. 1996. Verkenning. Kaapstad: Human \& Rousseau.

STEYTLER, KLAAS. 2000. Ons oorlog. Kaapstad: Tafelberg.

SWANEPOEL, EDUAN. 1991. Viljoen skiet ons literêre landskap oop (maar nie vir Boere-Calviniste nie). Vrye Weekblad: 25 April. Herdruk op http://www.agape.co.za Datum van gebruik: 12 Feb. 2005.

VAN DER MERWE, CHRIS. 1998. Die verstommendste verskietende ster ooit. http://www.litnet.co.za Datum van gebruik: 6 Feb. 2005.

VAN GORP, HENDRIK, GHESQUIERE, RITA, \& DELABASTITA, DIRK, reds. 1998. Lexicon van literaire termen. Met medewerking van Jan Flamend. Groningen: Nijhoff.

VAN JAARSVELD, F.A. 1992. Afrikanergeskiedskrywing: verlede, hede en toekoms. (In Bredekamp H.C., red. Afrikaanse geskiedskrywing en letterkunde: verlede, hede en toekoms. Bellville: Universiteit van WesKaapland se Instituut vir Historiese Navorsing. p. 119-136.)

VAN VUUREN, HELIZE. 1999. Buller se plan. http://www.litnet.co.za Datum van gebruik: 19 Jun. 2004. 
VAN VUUREN, HELIZE. 2002. Skrywersdagboeke van die Anglo-Boereoorlog. Stilet, XIII(1):88-102.

VENTER, L.S. 2002. Winterbach se roman Niggie verbeeldingryk. Die Beeld: 7 , 16 Des.

VILJOEN, LOUISE. 1999. Geheimsinnigheid van lewens uitgebeeld. http://www.boekwurm.co.za Datum van gebruik: 19 Jun. 2004.

VILJOEN, LOUISE. 1993. Die roman as polifonie: diskursiewe verskeidenheid in Lettie Viljoen se Belemmering. Journal of Literary Studies, 9(3 \& 4):313325.

VILJOEN, LOUISE. 2003. Die triekster met die verehoedjie. Insig, Junie. Herdruk op http://www.boekwurm.co.za Datum van gebruik 19 Jun. 2004.

VISAGIE, ANDRIES. 1999. Ingrid Winterbach op haar beste in Buller se plan. http://www.litnet.co.za Datum van gebruik: 19 Jun. 2004.

WHITE, HAYDEN. 1992. Historical emplotment and the story of truth. (In Friedlander, Saul, ed. Probing the limits of representation: Nazism and the "Final Solution". Cambridge: Harvard University Press. p. 37-53.)

WINTERBACH, INGRID. 1990. Belemmering. Kaapstad: Taurus.

WINTERBACH, INGRID. 1999. Buller se plan. Kaapstad: Human \& Rousseau.

WINTERBACH, INGRID. 2002. Niggie. Kaapstad: Human \& Rousseau.

WINTERBACH, INGRID. 2003 [1993]. Karolina Ferreira. Kaapstad: Human \& Rousseau.

WINTERBACH, INGRID. 2005. The elusive moth. Translated by Iris Gouws. Reworked and text revised by Ingrid Winterbach. Cape Town: Human \& Rousseau.

ZAMMITO, JOHN H. 1998. Ankersmit's postmodernist historiography: the hyperbole of "opacity". History and Theory, 37:330-346.

\section{Kernbegrippe:}

Anglo-Boereoorlogdagboeke

historiografiese metafiksie

intertekstualiteit

kreatiewe verwerking

\section{Key concepts:}

Anglo-Boer War diaries

creative adaptation

historiographial metafiction

intertextuality 
